\begin{tabular}{|c|c|c|}
\hline \multirow{3}{*}{$\begin{array}{l}\text { BENTHAM OPEN } \\
\text { CrossMark }\end{array}$} & $\begin{array}{c}\text { The Open Cybernetics \& Systemics } \\
\text { Journal }\end{array}$ & $\begin{array}{l}\text { The Open } \\
\text { Cybernelics \& Systemics } \\
\text { lournal }\end{array}$ \\
\hline & Content list available at: www.benthamopen.com/TOCSJ/ & 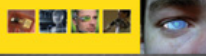 \\
\hline & $4110 x$ & \\
\hline
\end{tabular}

RETRACTION

\title{
Retraction Notice: Influence of Physical Ability Fast Recovery of Athletes Based on Movement Food Nutrition
}

Zhenfeng Zhang*

P.E. Department, Zhengzhou Institute of Aeronautical Industry Management, Zhengzhou, Henan, China

\section{RETRACTION}

The Publisher and Editor have retracted this article [1] in accordance with good ethical practices. After thorough investigations we believe that the peer review process was compromised. The article was published online on 08-10-2015.

\section{REFERENCE}

[1] Z. Zhang, "Influence of physical ability fast recovery of athletes based on movement food nutrition", Open Cybern. Syst. J., vol. 9, pp. 1756-1761, 2015.

(C) Zhenfeng Zhang; Licensee Bentham Open.

This is an open access article licensed under the terms of the Creative Commons Attribution-Non-Commercial 4.0 International Public License (CC BY-NC 4.0) (https://creativecommons.org/licenses/by-nc/4.0/legalcode), which permits unrestricted, non-commercial use, distribution and reproduction in any medium, provided the work is properly cited.

\footnotetext{
* Address correspondence to this author at the P.E. Department, Zhengzhou Institute of Aeronautical Industry Management, Zhengzhou, Henan, China; Tel: +358-6-3247476; Fax: +358-6-3247457; E-mail: hunter2011@foxmail.com
} 